\title{
Effect of Different Packaging Materials on the Physico-Chemical, Microbiological and Sensory Quality of Thirattupal during Storage
}

\author{
Harin Sutariya* and K. Jayaraj Rao \\ Dairy Technology Section, Southern Regional Station, ICAR- National Dairy \\ Research Institute, Adugodi, Bengaluru, Karnataka, India \\ *Corresponding author
}

\begin{tabular}{|c|c|}
\hline & A B S T R A C T \\
\hline $\begin{array}{l}\text { Ke y w or d s } \\
\text { Thirattupal, } \\
\text { Packaging } \\
\text { materials, Shelf } \\
\text { life, Sensory, } \\
\text { Physico-chemical } \\
\text { analysis, Microbial } \\
\text { analysis. }\end{array}$ & \multirow{3}{*}{$\begin{array}{l}\text { Thirattupal, a traditional Indian heat desiccated milk product of Tamil Nadu, } \\
\text { characterized by medium brown colour, granular texture and caramel flavour, is } \\
\text { expected to have good shelf life in comparison with other khoa-based sweets due } \\
\text { to low moisture content, higher amount of sugar and severe heat treatment applied } \\
\text { during its preparation. However, Thirattupal is also very much susceptible to } \\
\text { microbial spoilage due to unhygienic conditions adopted during its manufacture } \\
\text { and handling and its poor packaging. Hence, with a view to improve the shelf life } \\
\text { of Thirattupal by packaging interventions, the effect of different packaging } \\
\text { material (PS, LDPE, Laminates, Multilayer Pouch) on the sensory, physico- } \\
\text { chemical, and microbiological quality of Thirattupal during storage at } 30^{\circ} \mathrm{C} \text { was } \\
\text { studied. Based on the results obtained in the study, it was concluded that } \\
\text { Thirattupalcould be best preserved up to } 18 \text { days at room temperature }\left(30^{\circ} \pm 1 \mathrm{C}\right) \\
\text { without appreciable quality loss. }\end{array}$} \\
\hline Article Info & \\
\hline $\begin{array}{l}\text { Accepted: } \\
\text { 19 June } 2017 \\
\text { Available Online: } \\
\text { 10 July } 2017\end{array}$ & \\
\hline
\end{tabular}

\section{Introduction}

From decades, surplus milk is being converted to a series of indigenous milk products to preserve nutritional goodness of milk and to enhance shelf-life at prevalent high temperature environmental conditions. Milk based sweets are an integral part of the socio-cultural life of Indians and being consumed at different social events and religious occasions (Barnwal and Sen, 2014). It is estimated that about $50 \%$ of total milk produced in India is converted into traditional milk products (Bandyopadhyay and Khamrui, 2007). In addition to preservation of milk solids for longer time at room temperature, manufacture of traditional dairy products add value to milk and also provide considerable employment opportunity (Pal and Raju, 2010; Patil, 2013). Various traditional milk products like Khoa, Paneer, Chhana, Dahi, Kulfi, Shrikhand and several milk confections prepared from Khoa and Chhana such as Peda, Burfi, Gulabjamun, Milk cake, Kalakand, Rasogolla, Sandesh, etc are made in our country since ancient times because of their social, economic, religious, medicinal and cultural significance. In addition, there are many region-specific traditional products like Rabri, Basundi, Kunda, Thirattupal, Kheer, Payasam, etc which are known in specific region. Thirattupalis one such region 
specific heat desiccated milk product manufactured traditionally in Tamil Nadu and the product is also not well known in other parts of Southern India. Thirattupal is characterized by medium brown colour, granular texture and caramel flavour and having good shelf life. Most of Thirattupal sold in market is being made by small scale sweetmeat makers and sold in packaged (LDPE bags or butter paper lined cardboard boxes or polystyrene tubs), as well as in loose form with varying compositions. Though the people of the region relish the typical and lingering taste of Thirattupal, the product has no well-defined procedure of manufacture, which varies from manufacturer to manufacturer with regard to type of milk, fat content of milk, extent of desiccation, amount of sugar etc. Hence, the product prepared by some manufacturers is more popular than the others. Depending on the area of consumption, it differs in the intensity of characteristic colour and flavour. Milk sweets during storage undergo several physicochemical and microbiological changes making them unfit for human consumption.

The shelf life of a heat desiccated dairy product is generally determined by the conditions maintained post-production because such product is almost sterile when produced and hence such products get spoiled due to post-production contamination. The short shelf life of milk based heat desiccated sweets is one of the major constraints limiting their marketing in both domestic and export markets. However, due to poor handling and packaging, milk based heat desiccated sweet is most susceptible to microbial spoilage. One way of maintaining its hygienic condition, avoiding such contamination and physicochemical deterioration which restricts its shelf life is packaging in a suitable material employing advanced technological processes available in food sector.
Several studies have been reported for extension of shelf life of plain peda (Biradar et al., 1985; Reddy and Rajorhia, 1983; Banjare et al., 2015), brown peda (Londhe et al., 2012), and Kunda (Mahalingaiah, 2008), which are sugar containing products like Thirattupal, using different packaging materials. However, no information is available on the use of different packaging materials used for extension of shelf life of Thirattupal. Hence, there is a possibility of improving the shelf-life of Thirattupal by using an appropriate packaging material. In this work, evaluation of different packing materials was investigated with an objective to enhance the shelf-life of Thirattupal.

\section{Materials and Methods}

\section{Raw materials}

Good quality pooled cow milk was obtained from Cattle Yard of the Southern Regional Station, ICAR-NDRI, Bengaluru (India). Milk was standardized to $6 \%$ fat and $8.5 \%$ milk solids-not-fat (MSNF). Milk was 'clarified' before use to remove dirt and other extraneous matter. Sour Curd procured from Institute milk parlour was used for preparation of Thirattupal. Sugar, Jaggery and Cardamom powder used in product preparation were procured from local market.

\section{Preparation of Thirattupal}

Fresh cow milk was first filtered and standardized to $6 \%$ fat and $8.5 \% \mathrm{SNF}$ and then was taken in a double jacketed steam kettle and concentrated under constant stirring cum scraping. When partial concentration has taken place, sour curd was added to it @ 0.5 $\%$ of milk and heating was continued till semi-solid mass was formed. At this stage, a pleasant caramel flavour appeared and coarse granular texture developed. When the desired desiccation has taken place, sweetener (sugar 
+ jaggery)(1:1)@ $10.95 \%$ of milk was added. The concentration of milk was continued till it turned relatively firm. The concentration was stopped and at this stage, powdered cardamom $(0.01 \%)$ was added to impart typical flavour. The contents of kettle were spread on inner wall of kettle for cooling. After cooling, the Thirattupal was scraped and packed and stored at $30^{\circ} \mathrm{C}$ in different packaging materials for further analysis.

\section{Packaging of Thirattupal in different materials}

Hot Thirattupal $\left(85-90^{\circ} \mathrm{C}\right)$ from the kettle was packaged in selected 4 different packaging materials, viz. Polystyrene Tubs (P-1), Low density polyethylene (LDPE) pouches of $65 \mu$ thickness (P-2), Laminates (LDPE/PET/AL foil/LDPE films) of $135 \mu$ thickness (P-3) and Multilayer Pouches (LDPE/EVOH/LDPE) of $130 \mu$ thickness (P4) were used for packaging of Thirattupal. All the containers were of $200 \mathrm{~g}$ capacity.

\section{Storage of Thirattupal}

The Thirattupal samples packaged in different packaging materials were transferred to an incubator maintained at $30 \pm 1{ }^{\circ} \mathrm{C}$ for storage purpose for 18 days and samples were drawn at regular intervals for analysis. The drawing of samples was stopped when the overall acceptance of the samples was nearing 'like slightly' perception.

\section{Analyses}

Samples of Thirattupal were drawn at regular intervals and analyzed for physico-chemical (moisture, acidity, $\mathrm{pH}$, free fatty acids and free fat), microbiological (bacterial, yeast and mould and coliform counts) and sensory properties. Sealed containers were cut open and the contents were transferred to a mortar and ground thoroughly with a pestle to obtain a uniformly mixed sample, which was then used for various physicochemical analyses. For microbiological analyses, the packs containing Thirattupal were opened under sterile conditions in a laminar flow (BIS 1980a).

Physico-chemical characteristics viz. moisture content, acidity and $\mathrm{pH}$ were determined as per methods given in BIS (1981), BIS (1980b) and Awad et al., (2005), respectively. The method prescribed by Deeth et al., (1975) was used to estimate the FFA content of Thirattupal. Free fat was estimated by the method given by Hall and Hedrick, 1971.

All the samples of Thirattupal during storage were analyzed for standard plate count (SPC) and yeast and mould count by BIS (2002) and BIS (1999) methods, respectively.

\section{Sensory evaluation}

Thirattupal packed in the four packaging materials was transferred to well clean glass bowls, tempered to ambient temperature and served to a panel of expert judges chosen from the faculty of National Dairy Research Institute, Bengaluru in a sensory evaluation laboratory. The panelists were asked to evaluate the sensory quality in terms of colour and appearance, body and texture, flavour and overall acceptance using a 9 - point Hedonic scale, in which a score of 1 indicated 'dislike extremely' and a score of 9 indicated 'like extremely' (Amerine et al., 1965).

\section{Statistical analysis}

All the data were expressed as mean \pm standard deviation of mean calculated from three independent experiments. One-way analysis of variance (ANOVA) was applied and Duncan multiple range test was performed to measure the test of significance 
by post hoc test using SPSS 16.0 software (SPSS Italia, Bologna, Italy).

\section{Results and Discussion}

\section{Effect of packaging materials on physico- chemical and microbiological characteristics of Thirattupal during storage}

The physico-chemical characteristics of Thirattupal changed during storage at $30^{\circ} \mathrm{C}$ are presented in table 1 . The changes took place varied with the type of packaging material used. Level of moisture in the product plays a significant role on quality of the product during storage as far as bacterial activity, yeast and mould growth, browning reaction and the acceptability of the heat desiccated traditional products are concerned. As the storage progressed there was a slight loss of moisture as indicated by the decrease in analyzed moisture content in Thirattupal. The moisture loss was also influenced by the packaging material used which can be seen from table 1 . Initially there was no significant difference found in loss of moisture among packaging material. As the storage progressed the moisture loss was more in P-1 and P-2 as compared to P-3 and P-4. This was due to higher water vapour permeability of P-1 and P-2 than the other two materials. Kumar et al., (1975) and Goyal and Srinivasan (1989) reported that laminates containing aluminium foil provided good protection against moisture losses because of superior moisture barrier properties of the foil. Similar findings were observed by Mahalingaiah et al., (2014) during storage of Kunda in LDPE pouches at $30^{\circ} \mathrm{C}$. In another study, moisture loss was found with progression of storage period as reported by Londhe et al., (2012) for brown Peda and Jha et al., (2014) for lal Peda.

Acidity increase is the indication of deteriorative quality of any milk and milk products. The level of acidity also serves as an indicator to know the extent of microbial fermentation. Too high acidity may even influence the consumer's acceptability of the product. The observations relating to titratable acidity of Thirattupal samples packed in different packaging materials and stored at $30^{\circ} \mathrm{C}$ are presented in table 1 . It was observed that gradual increase was not significant up to $8^{\text {th }}$ day of storage, after that there was significant difference found in acidity during storage in all packaging materials. The similar findings were found by Londhe et al., (2012) who reported that increase in acidity of brown Peda during storage for 20 days at $30^{\circ} \mathrm{C}$ and Banjare et al., (2015) observed increase in acidity of Peda during storage for 12 days at $25^{\circ} \mathrm{C}$.

The changes in $\mathrm{pH}$ value cannot be directly correlated with change in acidity; still it was found that with the increase in acidity, the $\mathrm{pH}$ went on decreasing. The $\mathrm{pH}$ value found to be significant in between packaging materials during storage. The least decrease in $\mathrm{pH}$ was found in P-4. This may be attributable to continued disappearance of basic amino acids in the product (Namiki, 1988).

The increase in acidity could also be due to the action of microorganisms as well as production of organic acids during processing and storage. Kumar et al., (1997) also reported a decrease in $\mathrm{pH}$ of Peda during storage for 180 days at $20^{\circ} \mathrm{C}$. Londhe et al., (2012) found that decrease in $\mathrm{pH}$ of brown Peda during storage for 20 days at $30^{\circ} \mathrm{C}$ in cardboard boxes.

The Thirattupal samples were analyzed for free fatty acid content with a view to monitor the lipolytic changes during storage. The changes in FFA content of Thirattupal during storage are shown in table 1. The FFA content of Thirattupal increased significantly $(\mathrm{p}<0.05)$ with the progression of storage 
period. A gradual increase of fatty acids in Thirattupal samples was noticed during storage. The rate of increase in FFA was maximum in Thirattupal in $\mathrm{P}-1$ as compared to $\mathrm{P}-2$ stored at $30^{\circ} \mathrm{C}$ up to 16 days. The rate of increase in FFA was slower in Thirattupal in $\mathrm{P}-3$ as compared to $\mathrm{P}-4$ stored at $30{ }^{\circ} \mathrm{C}$ up to 18 days.

The release of free fat during the preparation of Thirattupal and presence of high moisture content could be responsible for lipolysis during storage, the rate of which is expected to be higher at higher temperature of storage. Oxygen is the causative factor for the occurrence of lipid oxidation in foods and in this case, elimination of oxygen from the package reduced the deteriorative changes. Similar findings were found by Jha et al.,
(2014) for lal Peda stored at $37^{\circ} \mathrm{C}$, Kumar et al., (2010) for Peda and Londhe et al., (2012) for brown Peda stored at $30^{\circ} \mathrm{C}$.

A certain amount of free fat in milk sweets like burfi and Peda is desirable because it imparts creamy taste and prevents stickiness. However, too much free fat accelerates lipid oxidation during storage. The changes in free fat content of Thirattupal during storage are shown in table 1. There was no significant increase found in free fat content of Thirattupal with the progression of storage period. The rate of increase in free fat was more in Thirattupal in P-1 and P-2 as compared to P-3 and P-4 stored at $30{ }^{\circ} \mathrm{C}$ during storage.

Fig.1 Changes in sensory scores of Thirattupal during storage at $30^{\circ} \mathrm{C}$
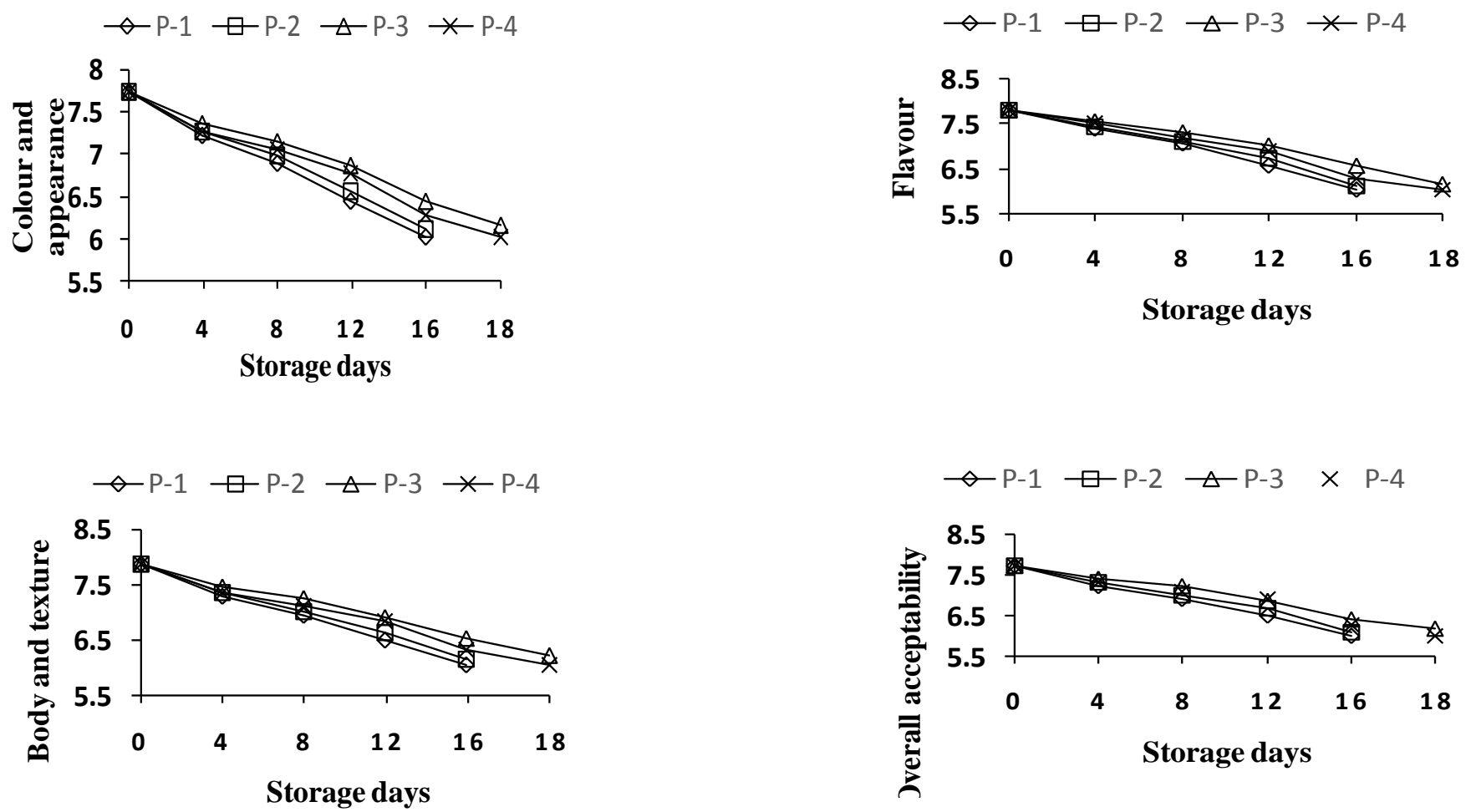
Table. 1 Changes in physico chemical parameters during storage of Thirattupal at $30^{\circ} \mathrm{C}$

\begin{tabular}{|c|c|c|c|c|c|c|c|}
\hline \multirow{2}{*}{\multicolumn{2}{|c|}{$\begin{array}{l}\text { Parameter } \\
\text { Physico Chemical }\end{array}$}} & \multicolumn{6}{|c|}{ Storage interval (Days) } \\
\hline & & 0 & 4 & 8 & 12 & 16 & 18 \\
\hline \multirow[t]{4}{*}{ Moisture } & P-1 & \multirow{4}{*}{$18.90 \pm 0.16$} & $18.15 \pm 0.12^{\mathrm{a}}$ & $17.31 \pm 0.10^{\mathrm{a}}$ & $16.37 \pm 0.04^{\mathrm{a}}$ & $15.04 \pm 0.17^{\mathrm{a}}$ & \\
\hline & $\mathrm{P}-2$ & & $18.24 \pm 0.11^{\mathrm{a}}$ & $17.38 \pm 0.14^{\mathrm{a}}$ & $16.44 \pm 0.04^{\mathrm{a}}$ & $15.11 \pm 0.17^{\mathrm{a}}$ & \\
\hline & P-3 & & $18.43 \pm 0.13^{\mathrm{a}}$ & $17.81 \pm 0.07^{\mathrm{a}}$ & $16.72 \pm 0.06^{b}$ & $15.78 \pm 0.09^{b}$ & $15.16 \pm 0.16^{\mathrm{a}}$ \\
\hline & $\mathrm{P}-4$ & & $18.41 \pm 0.12^{\mathrm{a}}$ & $17.66 \pm 0.07^{\mathrm{a}}$ & $16.57 \pm 0.07^{\mathrm{ab}}$ & $15.62 \pm 0.14^{\mathrm{ab}}$ & $15.04 \pm 0.17^{\mathrm{a}}$ \\
\hline \multirow[t]{4}{*}{ Acidity } & $\mathrm{P}-1$ & \multirow[t]{4}{*}{$0.65 \pm 0.01$} & $0.73 \pm 0.01^{\mathrm{a}}$ & $0.85 \pm 0.02^{\mathrm{a}}$ & $1.10 \pm 0.02^{b}$ & $1.27 \pm 0.01^{\mathrm{b}}$ & \\
\hline & $\mathrm{P}-2$ & & $0.75 \pm 0.02^{\mathrm{a}}$ & $0.85 \pm 0.04^{\mathrm{a}}$ & $1.07 \pm 0.02^{b}$ & $1.25 \pm 0.02^{b}$ & \\
\hline & $\mathrm{P}-3$ & & $0.72 \pm 0.01^{\mathrm{a}}$ & $0.78 \pm 0.01^{\mathrm{a}}$ & $0.93 \pm 0.01^{\mathrm{a}}$ & $1.12 \pm 0.01^{\mathrm{a}}$ & $1.27 \pm 0.01^{\mathrm{a}}$ \\
\hline & $\mathrm{P}-4$ & & $0.72 \pm 0.01^{\mathrm{a}}$ & $0.80 \pm 0.02^{\mathrm{a}}$ & $1.02 \pm 0.01^{\mathrm{ab}}$ & $1.13 \pm 0.01^{\mathrm{a}}$ & $1.32 \pm 0.01^{\mathrm{a}}$ \\
\hline \multirow[t]{4}{*}{$\mathrm{pH}$} & P-1 & \multirow[t]{4}{*}{$6.58 \pm 0.02$} & $6.35 \pm 0.02^{\mathrm{a}}$ & $6.23 \pm 0.01^{\mathrm{a}}$ & $6.01 \pm 0.01^{\mathrm{a}}$ & $5.69 \pm 0.01^{\mathrm{a}}$ & \\
\hline & $\mathrm{P}-2$ & & $6.39 \pm 0.01^{\mathrm{a}}$ & $6.26 \pm 0.01^{\mathrm{ab}}$ & $6.06 \pm 0.02^{a b}$ & $5.73 \pm 0.01^{\mathrm{a}}$ & \\
\hline & $\mathrm{P}-3$ & & $6.43 \pm 0.01^{\mathrm{a}}$ & $6.32 \pm 0.01^{\mathrm{bc}}$ & $6.12 \pm 0.01^{\mathrm{bc}}$ & $5.96 \pm 0.01^{b}$ & $5.69 \pm 0.02^{a}$ \\
\hline & $\mathrm{P}-4$ & & $6.43 \pm 0.01^{\mathrm{a}}$ & $6.34 \pm 0.02^{c}$ & $6.14 \pm 0.02^{c}$ & $5.99 \pm 0.02^{b}$ & $5.75 \pm 0.01^{\mathrm{a}}$ \\
\hline \multirow[t]{4}{*}{ FFA } & $\mathrm{P}-1$ & \multirow[t]{4}{*}{$10.66 \pm 0.08$} & $13.07 \pm 0.04^{\mathrm{b}}$ & $15.60 \pm 0.06^{\mathrm{c}}$ & $19.36 \pm 0.05^{b}$ & $22.17 \pm 0.08^{b}$ & \\
\hline & $\mathrm{P}-2$ & & $12.97 \pm 0.07^{\mathrm{b}}$ & $15.47 \pm 0.03^{c}$ & $19.25 \pm 0.07^{b}$ & $23.13 \pm 0.11^{\mathrm{c}}$ & \\
\hline & $\mathrm{P}-3$ & & $12.58 \pm 0.06^{\mathrm{a}}$ & $14.21 \pm 0.05^{\mathrm{a}}$ & $17.05 \pm 0.08^{\mathrm{a}}$ & $20.65 \pm 0.06^{\mathrm{a}}$ & $22.59 \pm 0.11^{a}$ \\
\hline & $\mathrm{P}-4$ & & $12.81 \pm 0.07^{\mathrm{ab}}$ & $14.60 \pm 0.08^{b}$ & $17.12 \pm 0.07^{\mathrm{a}}$ & $20.96 \pm 0.08^{a}$ & $23.10 \pm 0.12^{\mathrm{a}}$ \\
\hline \multirow[t]{4}{*}{ Free Fat } & P-1 & \multirow[t]{4}{*}{$39.38 \pm 0.92$} & $47.42 \pm 0.96^{\mathrm{a}}$ & $54.36 \pm 1.19^{b}$ & $62.35 \pm 1.21^{\mathrm{a}}$ & $68.58 \pm 1.05^{\mathrm{a}}$ & \\
\hline & $\mathrm{P}-2$ & & $46.34 \pm 0.82^{a}$ & $53.56 \pm 1.27^{\mathrm{ab}}$ & $63.20 \pm 1.15^{\mathrm{a}}$ & $68.11 \pm 1.10^{a}$ & \\
\hline & $\mathrm{P}-3$ & & $44.83 \pm 0.78^{a}$ & $51.39 \pm 1.11^{\mathrm{a}}$ & $58.35 \pm 1.06^{\mathrm{a}}$ & $64.01 \pm 1.09^{\mathrm{a}}$ & $67.73 \pm 0.92^{a}$ \\
\hline & $\mathrm{P}-4$ & & $45.52 \pm 0.80^{\mathrm{a}}$ & $52.19 \pm 1.15^{b}$ & $59.35 \pm 1.05^{\mathrm{a}}$ & $65.32 \pm 1.22^{\mathrm{a}}$ & $68.71 \pm 0.80^{a}$ \\
\hline
\end{tabular}

Values within a column with different superscripts are significantly different $(\mathrm{p}<0.05)$, Mean \pm S.D., $\mathrm{n}=3$ 
Table.2 Changes in sensory attributes during storage of Thirattupal at $30^{\circ} \mathrm{C}$

\begin{tabular}{|c|c|c|c|c|c|c|c|}
\hline \multirow{2}{*}{\multicolumn{2}{|c|}{$\begin{array}{l}\text { Parameter } \\
\text { Sensory attributes }\end{array}$}} & \multicolumn{6}{|c|}{ Storage interval (Days) } \\
\hline & & 0 & 4 & 8 & 12 & 16 & 18 \\
\hline \multirow{4}{*}{$\begin{array}{l}\text { Colour and } \\
\text { Appearance }\end{array}$} & $\mathrm{P}-1$ & \multirow[t]{4}{*}{$7.73 \pm 0.03$} & $7.22 \pm 0.05^{\mathrm{a}}$ & $6.89 \pm 0.03^{\mathrm{a}}$ & $6.44 \pm 0.04^{\mathrm{a}}$ & $6.01 \pm 0.05^{\mathrm{a}}$ & \\
\hline & $\mathrm{P}-2$ & & $7.26 \pm 0.04^{\mathrm{a}}$ & $6.98 \pm 0.04^{b}$ & $6.56 \pm 0.06^{b}$ & $6.11 \pm 0.05^{\mathrm{a}}$ & \\
\hline & $\mathrm{P}-3$ & & $7.37 \pm 0.03^{b}$ & $7.16 \pm 0.03^{\mathrm{d}}$ & $6.87 \pm 0.03^{\mathrm{d}}$ & $6.45 \pm 0.04^{\mathrm{c}}$ & $6.16 \pm 0.03^{b}$ \\
\hline & $\mathrm{P}-4$ & & $7.28 \pm 0.04^{\mathrm{ab}}$ & $7.07 \pm 0.04^{\mathrm{c}}$ & $6.77 \pm 0.02^{c}$ & $6.27 \pm 0.05^{b}$ & $6.02 \pm 0.05^{\mathrm{a}}$ \\
\hline \multirow{4}{*}{$\begin{array}{l}\text { Body and } \\
\text { Texture }\end{array}$} & $\mathrm{P}-1$ & \multirow[t]{4}{*}{$7.87 \pm 0.03$} & $7.29 \pm 0.03^{\mathrm{a}}$ & $6.94 \pm 0.03^{\mathrm{a}}$ & $6.48 \pm 0.05^{\mathrm{a}}$ & $6.04 \pm 0.04^{\mathrm{a}}$ & \\
\hline & $\mathrm{P}-2$ & & $7.34 \pm 0.03^{\mathrm{a}}$ & $7.02 \pm 0.04^{\mathrm{a}}$ & $6.62 \pm 0.07^{b}$ & $6.13 \pm 0.04^{\mathrm{a}}$ & \\
\hline & $\mathrm{P}-3$ & & $7.46 \pm 0.04^{b}$ & $7.24 \pm 0.04^{b}$ & $6.92 \pm 0.03^{c}$ & $6.52 \pm 0.06^{\mathrm{c}}$ & $6.21 \pm 0.04^{b}$ \\
\hline & $\mathrm{P}-4$ & & $7.36 \pm 0.03^{\mathrm{a}}$ & $7.12 \pm 0.03^{\mathrm{a}}$ & $6.84 \pm 0.03^{\mathrm{c}}$ & $6.31 \pm 0.03^{b}$ & $6.06 \pm 0.06^{\mathrm{a}}$ \\
\hline \multirow[t]{4}{*}{ Flavour } & $\mathrm{P}-1$ & \multirow[t]{4}{*}{$7.79 \pm 0.02$} & $7.38 \pm 0.03^{\mathrm{a}}$ & $7.04 \pm 0.02^{\mathrm{a}}$ & $6.57 \pm 0.02^{\mathrm{a}}$ & $6.03 \pm 0.02^{\mathrm{a}}$ & \\
\hline & $\mathrm{P}-2$ & & $7.43 \pm 0.03^{b}$ & $7.09 \pm 0.04^{\mathrm{a}}$ & $6.73 \pm 0.02^{b}$ & $6.13 \pm 0.03^{b}$ & \\
\hline & $\mathrm{P}-3$ & & $7.57 \pm 0.02^{\mathrm{d}}$ & $7.31 \pm 0.03^{\mathrm{c}}$ & $7.02 \pm 0.03^{\mathrm{d}}$ & $6.57 \pm 0.04^{\mathrm{d}}$ & $6.16 \pm 0.03^{b}$ \\
\hline & P-4 & & $7.50 \pm 0.03^{c}$ & $7.17 \pm 0.04^{b}$ & $6.91 \pm 0.03^{c}$ & $6.29 \pm 0.03^{c}$ & $6.04 \pm 0.04^{\mathrm{a}}$ \\
\hline \multirow{4}{*}{$\begin{array}{l}\text { Overall } \\
\text { Acceptability }\end{array}$} & $\mathrm{P}-1$ & \multirow[t]{4}{*}{$7.73 \pm 0.02$} & $7.21 \pm 0.06^{\mathrm{a}}$ & $6.91 \pm 0.05^{\mathrm{a}}$ & $6.49 \pm 0.03^{\mathrm{a}}$ & $5.99 \pm 0.04^{\mathrm{a}}$ & \\
\hline & $\mathrm{P}-2$ & & $7.31 \pm 0.02^{b}$ & $7.02 \pm 0.03^{b}$ & $6.69 \pm 0.03^{b}$ & $6.08 \pm 0.04^{\mathrm{a}}$ & \\
\hline & P-3 & & $7.42 \pm 0.03^{\mathrm{c}}$ & $7.24 \pm 0.03^{\mathrm{d}}$ & $6.88 \pm 0.04^{\mathrm{d}}$ & $6.41 \pm 0.06^{\mathrm{c}}$ & $6.17 \pm 0.06^{\mathrm{b}}$ \\
\hline & $\mathrm{P}-4$ & & $7.33 \pm 0.03^{b c}$ & $7.12 \pm 0.03^{c}$ & $6.89 \pm 0.03^{c}$ & $6.27 \pm 0.04^{b}$ & $5.99 \pm 0.06^{\mathrm{a}}$ \\
\hline
\end{tabular}

Values within a column with different superscripts are significantly different $(p<0.05)$, Mean \pm S.D., $n=3$

Table.3 Changes in microbial parameters during storage of Thirattupal at $30^{\circ} \mathrm{C}$

\begin{tabular}{|c|c|c|c|c|c|c|c|}
\hline \multirow{2}{*}{\multicolumn{2}{|c|}{$\begin{array}{l}\text { Parameter } \\
\text { Microbiological } \\
\text { attributes }\end{array}$}} & \multicolumn{6}{|c|}{ Storage interval (Days) } \\
\hline & & 0 & 4 & 8 & 12 & 16 & 18 \\
\hline \multirow[t]{4}{*}{$\mathrm{SPC}$} & P-1 & \multirow[t]{4}{*}{$2.18 \pm 0.06$} & $2.67 \pm 0.03^{b}$ & $2.83 \pm 0.05^{\mathrm{b}}$ & $3.03 \pm 0.04^{\mathrm{b}}$ & $3.17 \pm 0.06^{\mathrm{b}}$ & \\
\hline & $\mathrm{P}-2$ & & $2.67 \pm 0.02^{b}$ & $2.85 \pm 0.05^{b}$ & $3.03 \pm 0.04^{\mathrm{b}}$ & $3.12 \pm 0.07^{\mathrm{b}}$ & \\
\hline & $\mathrm{P}-3$ & & $2.52 \pm 0.07^{\mathrm{a}}$ & $2.63 \pm 0.07^{\mathrm{a}}$ & $2.80 \pm 0.06^{\mathrm{a}}$ & $2.97 \pm 0.04^{\mathrm{a}}$ & $3.07 \pm 0.04^{\mathrm{a}}$ \\
\hline & $\mathrm{P}-4$ & & $2.44 \pm 0.05^{\mathrm{a}}$ & $2.57 \pm 0.05^{\mathrm{a}}$ & $2.76 \pm 0.09^{\mathrm{a}}$ & $2.95 \pm 0.05^{\mathrm{a}}$ & $3.04 \pm 0.05^{\mathrm{a}}$ \\
\hline \multirow{4}{*}{$\begin{array}{l}\text { Yeast and } \\
\text { Mould }\end{array}$} & P-1 & \multirow[t]{4}{*}{$1.19 \pm 0.09$} & $1.54 \pm 0.05^{b}$ & $1.70 \pm 0.04^{b}$ & $1.90 \pm 0.02^{\mathrm{c}}$ & $2.00 \pm 0.02^{\mathrm{c}}$ & \\
\hline & $\mathrm{P}-2$ & & $1.39 \pm 0.07^{\mathrm{ab}}$ & $1.65 \pm 0.04^{b}$ & $1.87 \pm 0.02^{\mathrm{c}}$ & $1.98 \pm 0.02^{\mathrm{c}}$ & \\
\hline & $\mathrm{P}-3$ & & $1.29 \pm 0.06^{\mathrm{a}}$ & $1.47 \pm 0.04^{\mathrm{a}}$ & $1.74 \pm 0.03^{\mathrm{a}}$ & $1.84 \pm 0.03^{\mathrm{a}}$ & $1.90 \pm 0.02^{\mathrm{a}}$ \\
\hline & P-4 & & $1.47 \pm 0.09^{b}$ & $1.65 \pm 0.05^{\mathrm{b}}$ & $1.81 \pm 0.03^{b}$ & $1.93 \pm 0.03^{\mathrm{b}}$ & $1.95 \pm 0.02^{\mathrm{b}}$ \\
\hline
\end{tabular}

Values within a column with different superscripts are significantly different $(p<0.05)$, Mean \pm S.D., $n=3$ 
Fig.2 Changes in microbial count of Thirattupal during storage at $30^{\circ} \mathrm{C}$

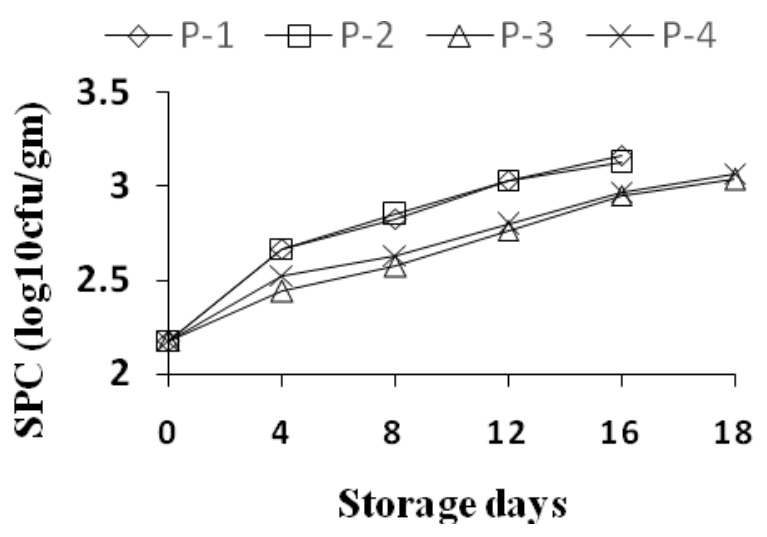

Effect of packaging materials on sensory characteristics of Thirattupal during storage

Sensory evaluation is one of the important methods to judge the quality of food, in addition to physico-chemical as well as microbiological quality. Based on the sensory evaluation, food can be accepted or rejected. The decreasing trend was found during storage in all samples of Thirattupal irrespective of packaging materials (Fig. 1). The sensory score presented in table 2 also showed significant $(\mathrm{P}<0.05)$ effect of packaging materials on all the sensory attributes of Thirattupal during storage.

The sensory scores decreased, but remained well within acceptable limits during storage period. The decrease in colour and appearance score was significant between packaging materials. The product slightly got dried up due to evaporation of moisture which also resulted in decrease in colour and appearance scores. Acharya and Agrawal (2010) observed that khoa was acceptable up to 23 days at $25^{\circ} \mathrm{C}$ in 3-layer laminated package. Banjare et $a l$., (2015) reported that Peda stored in LDPE pouches was acceptable up to 10 days. Londhe et al., (2012) reported brown Peda can be stored in cardboard boxes lined with butter paper up to 20 days at $30^{\circ} \mathrm{C}$.

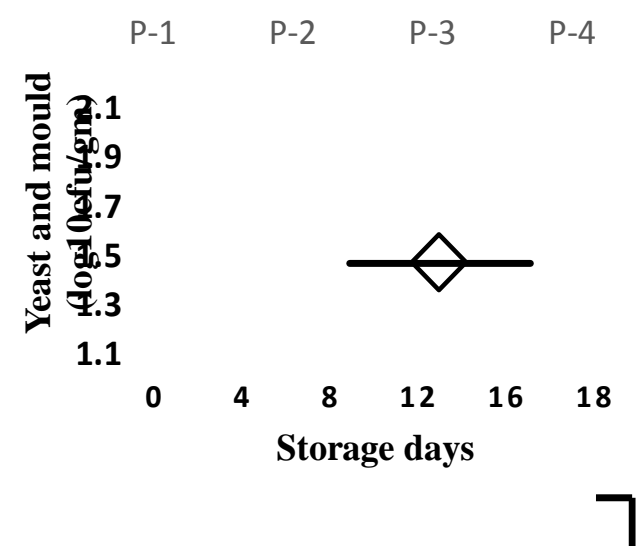

Mahalingaiah et al., (2014) observed that Kunda was acceptable up to 42 days at $30^{\circ} \mathrm{C}$.

The body and texture scores also decreased significantly $(\mathrm{p}<0.05)$ during storage because of dryness and hardness caused by loss of moisture. Acharya and Agrawal (2010) reported for khoa that it was acceptable up to 23 days at $25^{\circ} \mathrm{C}$ in 3-layer laminated package.

Flavour which is the combination of smell and taste is the prime attribute for acceptance or rejection of a food product. There was significant decrease in flavour score of Thirattupal during storage. However, none of the judges reported the presence of any objectionable off flavour such as oxidized, sour, rancid etc. during the entire period of storage even though increase was found in FFA and acidity contents. The decrease in flavour scores may be attributed to slight loss of freshness, which is inherent with any food product. Acharya and Agrawal (2010) observed that khoa was acceptable up to 9 days at $25^{\circ} \mathrm{C}$ in normal LDPE pouches. Banjare et al., (2015) reported that Peda stored in LDPE pouches was acceptable up to 10 days. Overall acceptance scores are comprehensive evaluation of food products for acceptance. Because of decrease in all scores viz. flavour, colour and appearance and body and texture scores it was found that 
overall acceptability score was also affected significantly. The samples packed in P-1 and P-2 were considered little acceptable after 16 days of storage because of loss of freshness due to moisture loss and getting dried even though sensory score was remained in acceptable limit. The samples packed in P-3 and P-4 was acceptable up to 18 days of storage due better barrier properties. The P-4 was suggested as best packaging material due it has higher sensory score compared to P-3.

\section{Microbiological changes in Thirattupal during storage}

The results of microbiological changes in Thirattupal packaged under different packaging materials during storage are depicted in figure 2. Initial standard plate count in all the samples ranged from 2.18 to 2.25 per gram $\left(\log _{10}\right)$. During storage increasing trend was found in all the samples with regard to standard plate count. The rate of increase was higher in case of P-1and P-2 samples compared P-3 and P-4. However, studies were discontinued further due to loss of freshness and rejection of samples by the sensory panelists. The similar trend was observed by Palit and Pal (2005) for burfi and Londhe et al., (2012) for brown Peda. Coliform count was checked for any post processing contamination and it was found nil. The absence of coliform count indicates that the product packed in hygienic conditions. The most important single factor which is responsible for limiting shelf life of Indian traditional dairy products such as peda, burfi, kalakand is mould growth. In present study, it was observed that the yeast and mould count of Thirattupal increased significantly $(\mathrm{p}<0.05)$ with the progression of storage period. However there was no visible growth of mold on surface of sample at the end of storage days. Yeast and mould counts were not detected in fresh samples packaged in different packaging materials. The same was observed by Londhe et al., (2012) for brown Peda (Table 3).

In conclusion, an attempt was made to study the effect of different packaging materials during storage at $30^{\circ} \mathrm{C}$ on Thirattupal - a heat desiccated dairy product of Tamil Nadu. From the results obtained, it was found that there was a decrease in moisture, sensory scores and increase in acidity, $\mathrm{pH}$, free fatty acid and free fat at different rates in all the samples packaged in different packaging materials. Accordingly, the shelf life of the product was found to differ considerably with different packaging materials. The product packaged in LDPE pouches and PS tubs was found to keep good only for 16 days and the main cause of spoilage was excessive hardening of the product. Packaging in Laminates and Multilayer pouches provided a shelf life up to 18 days and the main cause of loss of freshness and hardening of product. Hence, it was recommended that Thirattupal be packed in multilayer pouches for storage up to 18 days at $30^{\circ} \mathrm{C}$.

\section{Acknowledgement}

Authors express sincere thank Head, Southern Regional Station and In-charge Dairy Technology Section for help in all aspects of the project and in conducting experimental trials. The first author gratefully acknowledges the financial assistance received from ICAR-NDRI, Karnal (Deemed University), and University Grant Commission, India for carrying out the present study.

\section{References}

Acharya, P. P. and Agrawal, J. 2010 Effect of packaging materials and modified atmosphere packaging on the shelf-life of khoa. Nepal J. Sci. Technol., 11: 8794. 
Amerine, M.A., Pangborn, R.M.and Edward, B. 1965 Principles of sensory evaluation of food. Academic, New York.

Awad, S., Hassan, A. N. and Halaweish, F. 2005. Application of exopolysaccharide producing cultures in reduced cheese Cheddar cheese: Composition and proteolysis. Journal of Dairy Science, 8: 4195-4203.

Bandyopadhyay, P. and Khamrui, K. 2007. Technological advancement on traditional Indian desiccated and heatacid coagulated dairy products. Bulletin-International Dairy Federation, 415: 4.

Banjare, K., Kumar, M. and Goel, B. K. 2015. Effect of storage on chemical, textural and sensory attributes of traditional indigenous sweet peda. Asian J. Dairy and Food Res., 34(2): 104-108.

Banjare, K., Kumar, M., Goel, B. K. and Uprit, S. 2015. Studies on chemical, textural and sensory characteristics of market and laboratory peda samples manufactured in Raipur city of Chhattisgarh. Oriental J. Chem., 31(1): 231-238.

Barnwal, I. C. and Sen, D. C. 2014. Delicacy of oil fried Indian milk based sweets. Indian Dairyman, 3: 54-59.

Biradar, U. S., Dev, D. K. and Ingle, U. 1985. Shelf life extension of pedha. J. Food Sci., 50(1): 51-55.

BIS 1980a. SP: 18 Hand book of food analysis Part I General methods. Bureau of Indian Standards, New Delhi.

BIS 1980b. IS: 4883 Indian standards specification for khoa. Bureau of Indian Standards, New Delhi.

BIS 1981. SP: 18 Part XI Hand book of food analysis Part XI Dairy Products. Bureau of Indian Standards, New Delhi.

BIS 1999. IS: 5403 Methods for Yeast and Mold count of foodstuffs and animal feeds, Bureau of Indian Standards, Manak Bhavan, New Delhi.
BIS 2002.IS: 5402 General Guidance for the enumeration of micro-organism, Bureau of Indian Standards, Manak Bhavan, New Delhi.

Deeth, H.C., Fitx-Gerald, C.H. and Wood, A.F. 1975. A convenient method for determining extent of lipolysis in milk. Aust. J. Dairy Technol., 30(3): 109-111.

Goyal, G. K. and Srinivasan, M. R. 1989. Role of flexible packages on the microbiological quality of khoa during low-temperature storage. Asian J. Dairy Res., 8(2):95-99.

Hall, C. W. and Hedrick, T. L. 1971. Drying of milk products. AVI Publisher Company West port Connecticut, U.S.A., pp. 250-255.

Jha, A., Kumar, A., Jain, P., Om, H., Singh, R. and Bunkar, D. S. 2014. Physicochemical and sensory changes during the storage of lal peda.J. Food Sci. Technol., 51(6): 1173-1178.

Kumar, A., Rajorhia, G. S. and Srinivasan, M. R. 1975. Effect of modern packaging materials on the keeping quality of khoa. J. Food Sci. Technol., 12: 172177.

Kumar, M., Beniwal, B. S. and Rai, D. C. 2010. Effect of antioxidant on shelf life of Khoa under refrigerated conditions. Egypt J. Dairy Sci., 38:211-218.

Kumar, R., Badyopadhyay, P. and Punjrath, J.S. 1997. Shelf life extension of peda using different packaging techniques. Indian J. Dairy Sci., 50(1): 40-49.

Londhe, G., Pal, D. and Raju, P. N. 2012. Effect of packaging techniques on shelf life of brown peda, a milk-based confection. LWT-Food Sci. Technol., 47(1): 117-125.

Mahalingaiah, L. 2008. Development of technology for manufacture, packaging and preservation of Kunda. Ph.D. Thesis submitted to Karnataka Veterinary, Animal and Fisheries Sciences University, Bidar. 
Mahalingaiah, L., Venkateshaiah, B. V., Kulkarni, S., and Rao, K. J. 2014. Study on the effect of packaging materials on the physico-chemical, microbiological and sensory quality of kunda. J. Food Sci. Technol., 51(5), 1000-1005.

Namiki, M. 1988. Chemistry of Maillard reactions: recent studies on the browning reaction mechanism and developments of antioxidants and mutagens. Adv Food Sci., 32:115-184.

Pal, D. and Raju, P. N. 2010. Traditional Indian dairy products with functional attributes: status and scope. Indian Food Ind., 29(1): 13-21.

Palit, C., and Pal, D. 2005. Studies on mechanized production and shelf life extension of burfi. Indian J. Dairy Sci., 58(1), 12-16.
Patil, G.R. 2013. Current Scenario, scope and challenges of traditional Indian dairy products. In: "Compendium of national training on: advances in production, functional, rheological and quality aspects of traditional Indian dairy products", NDRI, Karnal, October 8-18, pp. 1-11.

Reddy, G. R., Reddy, K. S., Mandokhot, U. V. and Chandiramani, N. K. 1983. Survey and growth of micro flora in khoa at different storage conditions In: Proceedings of the symposia on biology of virus plasmids and biotechnology; Microorganisms in Agriculture and Ecology. In 24th Annual Conference of Association of Microbiologist of India, Hyderabad, Nov13.

\section{How to cite this article:}

Harin Sutariya and Jayaraj Rao, K. 2017. Effect of Different Packaging Materials on the Physico- Chemical, Microbiological and Sensory Quality of Thirattupal during Storage. Int.J.Curr.Microbiol.App.Sci. 6(7): 1529-1539. doi: https://doi.org/10.20546/ijcmas.2017.607.183 